\title{
Pollination and Growth of Pollen Tubes in Common Juniper (Juniperus communis L.: Cupressaceae Rich. ex Bartl.)
}

\author{
Mikhail V. Surso* \\ Federal Center for Integrated Arctic Research RAS \\ 23 Severnoi Dviny, Arkhangelsk, 163000, Russia
}

Received 27.12.2018, received in revised form 04.02.2019, accepted 13.03.2019

Pollination and fertilization are crucial stages in sexual reproduction of coniferous plants. The period of high concentrations of airborne juniper pollen in the pollination season lasts no more than 4-6 hours within one calendar day. This event occurs in precisely the same way every year regardless of weather conditions in the reception period and specific growth conditions of the juniper. The study addresses the influence of external agents on dynamics of exudation of a juniper pollination droplet. The duration of exudation and the volume of secretory liquid exuded by tissues of ovules are determined by the presence of external agents on the surface of the pollination droplet, their sizes, and their physical and chemical properties. The chemical composition of the pollination droplet has been studied. About 40 substances belonging to different classes of organic compounds have been identified in the volatile fractions of the pollination droplet. Sugars of the juniper pollination droplet are only represented by two monosaccharides: glucose and galactose. The major amino acids are arginine, aspartic and glutamic acids. Results of the study confirm the complex chemical composition and multi-functionality of the juniper pollination droplet. The pollination mechanism of the juniper is effective and selective. Pollination failure leads to degradation and necrosis of tissues of ovules and macrostrobili. The morphological structure of pollen grains of the juniper predetermines processes of pollen germination at early stages. The hydrophilic capsule formed after pollen hydration facilitates exine rupture and shedding. This capsule is retained until fertilization occurs. The distal tip of the pollen tube stays in the capsule throughout its growth period. In the in vitro culture, pollen tubes of the juniper develop non-uniformly. To assess juniper pollen viability, it is necessary to take into account the stage of development of pollen tubes.

Keywords: common juniper, pollination, pollination droplet, ovules, pollen grains, pollen tubes.

Citation: Surso M.V. Pollination and growth of pollen tubes in common juniper (Juniperus communis L.: Cupressaceae Rich. ex Bartl.). J. Sib. Fed. Univ. Biol., 2019, 12(1), 48-70. DOI: 110.17516/1997-1389-0288.

(C) Siberian Federal University. All rights reserved

This work is licensed under a Creative Commons Attribution-NonCommercial 4.0 International License (CC BY-NC 4.0).

* Corresponding author E-mail address: surso@fciarctic.ru 


\section{Опыление и рост пылыцевых трубок}

у можжевельника обыкновенного

\section{(Juniperus communis L.: Cupressaceae Rich. ex Bartl.)}

M.B. Cypco

Федеральный исследовательский цуентр комплексного изучения Арктики РАН

Россия, 163000, Архангельск, наб. Северной Двиньл, 23

Опьление и оплодотворение являются важными и наиболее ответственными этапами в половой репродукции хвойных растений. Период массового пыления у можжевельника составляет не более 4-6 ч и укладывается в одни календарные сутки. Эта закономерность сохраняется из года в год и не зависит ни от погодных условий в период рецептации, ни от особенностей места произрастания можжевельника. Изучено влияние внешних агентов на динамику экссудации опьлительной капли у можжевельника. Продолжительность экссудации и объем выделяемого секрета тканями семязачатков зависят от наличия на поверхности опылительной капли внешних агентов, их размеров и физико-химических свойств. Изучен химический состав опьлительной капли. В составе ее летучих фракций идентифицировано около 40 вещчеств, принадлежащчих к различным классам органических соединений. В состав сахаров опылительной капли можжевельника входят только два моносахарида: глюкоза и галактоза. В аминокислотном составе преобладают аргинин, аспарагиновая и глутаминовая кислоты. Результаты исследований подтверждают сложный химический состав и многофункичиональность опылительной капли. Механизм опьления у можжевельника является эффективным и избирательным. Отоутствие опьления приводит к деструктивному типу развития тканей семязачатков и макростробилов. Морфологическое строение пыльцеевых зерен можжевельника предопределяет процессы прорастания пыльц̧ы на ранних стадиях. Гидрофильная капсула, образующаяся при гидратации пьльиьь, способствует разрыву и сбрасыванию экзины. Эта капсула сохраняется до момента оплодотворения. В ней же остается и дистальный кончик пыльцевой трубки в течение всего времени ее роста. В культуре in vitro развитие пыльцевых трубок можжевельника протекает неравномерно. При определении показателя жизнеспособности пыльијы необходимо учитывать стадию формирования пыльцевых трубок.

Ключевые слова: можжевельник обыкновенный, опьление, опьлительная капля, семязачатки, пьльиевое зерно, пыльцевая трубка.

\section{Введение}

Проблеме опыления у голосеменных посвящена обширная библиография, которая обобщена в ряде обзоров (Doyle, 1945; Owens et al., 1998). Отдельные вопросы опыления у голосеменных рассматриваются в работах многих авторов. Закономерности опыления y Coniferales, в том числе и у Cupressaceae, 
освещались в ряде работ (McWilliam, 1958; Owens et al., 1987; Anderson, Owens, 2000). Важную роль в процессе опыления у большинства хвойных видов сем. Cupressaceae, Taxaceae, Cephalotaxaceae и многих видов сем. Podocarpaceae и Pinaceae играет опылительная капля, скапливающаяся на верхушке микропиле семяпочки в период рецептации (Ругузов и др., 1992; Ругузова, 2004; Singh, 1978). Функциональные свойства секреторной капли хвойных видов обсуждались в работах ряда авторов (Gelbart, von Aderkas, 2002; Poulis et al., 2005; Mugnaini et al., 2007b; Wagner et al., 2007; Nepi et al., 2009).

Успешность опыления у анемофильных хвойных видов обусловлена многими факторами. Важнейшими из этих факторов являются объемы продуцируемой пыльцы, сроки раскрытия микроспорангиев, продолжительность периода рассеивания пыльцы, метеоусловия в период пыления, время суток, в которое происходит массовый вылет пыльцы и связанные с этим восходящие и нисходящие потоки воздуха и турбулентность, аэродинамические характеристики пыльцевых зерен, эффективность механизмов улавливания пыльцы рецептивными семязачатками. Наименее изученным в этом плане остается можжевельник.

Пыльцевой режим в природных и искусственных популяциях хвойных изучался в основном для видов сем. Pinaceae (Дылис, 1948; Некрасова, 1983; Villar et al., 1984; Nikkanen, 2001; Nikkanen et al., 2002; Williams, 2008). Изучению общей динамики пыльцевого режима у Cupressaceae посвящено всего несколько работ (Belmonte et al., 1999; Sabariego et al., 2012). Проведение этих исследований во многом обусловлено задачами клинической аллергологии и иммунологии (Altintaş et al., 2004; Diaz de la Guardia et al., 2006; Ianovici et al., 2013). В последнее время эти исследо- вания все более ассоциируются с проблемами трансграничного переноса пыльцевых мacc (Rogers, Levetin, 1998; Necib, Boughediri, 2016; Puljak et al., 2016) и эволюцией опыления (Friedman, Barrett, 2009).

Эволюция механизмов опыления у голосеменных шла от энтомо- к анемофилии (Labandeira et al., 2007), что наложило отпечаток на строение и функциональные особенности тканей семязачатков и пыльцевых зерен хвойных видов. Можжевельник обыкновенный - облигатный двудомный вид. Как и большинство хвойных растений, можжевельник обыкновенный является анемофильным видом, хотя, по-видимому, для него не исключены случаи энтомофилии.

Морфология пыльцы видов сем. Cupressaceae и рода Juniperus рассматривается в работах многих авторов (Southworth, 1986; Bortenschlager, 1990; Kurmann, 1994). Механизм сбрасывания экзины при прорастании пыльцы, особенности роста и развития пыльцевых трубок и микрогаметогенез у можжевельника рассматриваются в работах Дьюо (Duhoux, 1972a, 1972b, 1974, 1982), Фернандо с соавт. (Fernando et al., 2005), Такасо и Оуэнса (Takaso, Owens, 2008) и некоторых других авторов.

Целью исследований стало изучение процессов опыления и биологии прорастания пыльцы у можжевельника обыкновенного.

\section{Материалы и методы}

\section{Сбор пыльць}

Ветви со зрелыми микростробилами срезались с мужских растений можжевельника до начала раскрывания микроспорангиев. Ветви с микростробилами помещались в сосуды с водой, которые ставились на листы газетной бумаги таким образом, чтобы по возможности большая часть пыльцы после высыпания оказалась на бумаге. Пыльца 
просеивалась через мелкие сита и хранилась в стеклянных пробирках, неплотно закрытых ватными пробками, в эксикаторах над хлористым кальцием в холодильнике при температуре $1 . .2{ }^{\circ} \mathrm{C}$ для дальнейшего изучения.

\section{Электронная микроскопия}

Электронно-микроскопическое изучение пыльцевых зерен проводилось при помощи сканирующего электронного микроскопа Zeiss SIGMA VP (Carl Zeiss, Германия). Гидратированную пыльцу лиофильно высушивали, наклеивали на липкую основу объектодержателя и после напыления технического золота сканировали при различных режимах увеличения.

\section{Проращиивание пыльщ̧ы}

Пыльцу проращивали in vitro во влажных камерах (чашках Петри) в термостате при $26,5^{\circ} \mathrm{C}$ на 1,0\%-ном (w/v) агаре с 5,0\%ной (w/v) сахарозой. Продолжительность инкубирования зависела от скорости (интенсивности) зарастания среды мицелием грибов. Определялось процентное соотношение пыльцевых зерен по следующим категориям: 1 - пыльцевые зерна не проросли; 2 - пыльцевые зерна образовали гидрофильную капсулу и сбросили экзину, микроспора не проросла в микрогаметофит и остается в центре гидрофильной капсулы; 3 - микроспора проросла в двухклеточный микрогаметофит, формирующаяся пыльцевая трубка овальной или туфелькообразной формы полностью либо почти целиком находится внутри гидрофильной капсулы; 4 - сформировалась пыльцевая трубка, проксимальный кончик которой вышел из гидрофильной капсулы. Средняя длина пыльцевой трубки определялась по 100 случайно взятым проросшим пыльцевым зернам 4-й категории или непосредственно на мониторе компьютера, или при помощи окуляр-микрометра. Для наблюдений за делениями и перемещениями ядерных структур в растущих пыльцевых трубках проращивание пыльцы осуществлялось в дистиллированной воде по методу «висячей капли». Пыльцевые трубки не окрашивались или окрашивались различными красителями, выбор которых зависел от целей исследований.

\section{Пьльцеевой режим}

Для изучения динамики пыльцевого режима в природных популяциях можжевельника использовались пыльцеуловители, конструктивно представляющие недельный часовой механизм с вращающимся барабаном, на который накладывалась прозрачная полиэтиленовая пленка с нанесенным тонким слоем технического вазелина. Барабан герметично закрывался коробом из тонкого оргстекла. На передней стороне короба делалась вертикальная приемная щель шириной 1,2 мм для улавливания пыльцы. Пыльцеуловители работали по принципу флюгера, т.е. приемная щель всегда располагалась навстречу горизонтальному потоку воздуха. Пыльцеуловители устанавливались на шесты высотой 1,3 м вблизи модуляторов пыльцы. Одновременно с установкой пыльцеуловителей рядом с ними устанавливались недельные термографы, работающие синхронно с пыльцеуловителями. После съемки регистрирующей пленки концентрация пыльцы в воздухе на каждом временном отрезке определялась светомикроскопически при помощи пленкиподложки со стороной квадрата учета 1 мм. Таким образом, получался непрерывный временной ряд (динамика) плотности пыльцевого облачка в заданной точке.

\section{Динамика экссудации овулярного секрета}

Целью экспериментов было изучение влияния внешних агентов на динамику экс- 
судации и ретракции опылительной капли у можжевельника. Ветви длиной 50-70 см с рецептивными макростробилами срезались с женских растений до начала пыления единичных мужских растений. В микропилярной части у большинства семязачатков к этому времени уже было отмечено появление опылительной капли. Ветви укладывались срезами вниз во влажный сфагнум в неплотно упакованные и герметично закрытые полиэтиленовые пакеты. В течение 3 ч они доставлялись в лабораторию. Для опытов использовались более короткие (15-30 см) верхние отрезки, которые ставились в сосуды с водой. Во время опытов вода доливалась по мере необходимости. Спустя сутки проводилась первичная морфометрия размеров опылительных капель. Измерения диаметра капель (перпендикулярно оси микропилярного канала) производили при помощи измерительной шкалы бинокулярного микроскопа МБС-10. В опыте 2015 г. испытывали 3 варианта опыления: опыление жизнеспособной пыльцой можжевельника (сбор прошлого года), опыление свежесобранной пыльцой сосны обыкновенной, без опыления. В опыте 2016 г. испытывали 5 вариантов опыления: опыление жизнеспособной пыльцой можжевельника (сбор прошлого года), опыление силикагелями с диаметром частиц 25-40, 63-100 и 160-200 мкм, без опыления. Пыльца и силикагели наносились на поверхность капель путем рассеивания с близкого расстояния при помощи препаровальной иглы. Результативность опыления контролировалась визуально. Измерения диаметра капли в опытах проводили с периодичностью 4-30 ч до полного исчезновения капли.

\section{Химический состав опьлительной капли}

Для изучения химического состава секреторную жидкость, скапливающуюся в виде капелек на кончиках семязачатков в период рецептации, извлекали с помощью узких полосок тонкой фильтровальной бумаги. Полоски до использования хранили в герметично закрытых пластиковых пробирках в морозильной камере холодильника при минус $20^{\circ} \mathrm{C}$. Качественный состав летучих фракций органических соединений в опылительной капле можжевельника анализировали при помощи газового хромато-масс-спектрометра QP-2010 Ultra (Shimadzu, Япония). Условия хроматографирования: колонка капиллярная Rtx-5MS, диаметр 0,25 мм, толщина неподвижной фазы 0,25 мкм, длина колонки 30 м; ввод автосамплером, объем пробы 1 мкл; ввод пробы без деления потока; температура устройства ввода $250{ }^{\circ} \mathrm{C}$; газ-носитель - гелий; управление потоком газа - постоянное давление; поток через колонку - 1,0 мл/мин; начальная температура термостата $40^{\circ} \mathrm{C}$, изотерма 5 мин; подъем со скоростью $2,5^{\circ} \mathrm{C} / \mathrm{мин}$ до $260{ }^{\circ} \mathrm{C}$, изотерма 20 мин; температура устройства сопряжения $250{ }^{\circ} \mathrm{C}$; температура ионного источника $230{ }^{\circ} \mathrm{C}$; энергия ионизации 70 эВ; напряжение на детекторе 0,87 кВ; режим работы масс-детектора: Scan (сканирование диапазона); диапазон сканирования масс: 35-450. Аминокислотный состав опылительной капли и пыльцы можжевельника определяли с помощью аминокислотного анализатора BioChrom 30+ (Biochrom, Великобритания). Условия хроматографирования: колонка - Oxidised Feedstuff Column (Biochrom), термостат колонки $37{ }^{\circ} \mathrm{C}$, температура реакционной ячейки $135^{\circ} \mathrm{C}$, реагент - нингидрин. Состав сахаров опылительной капли и пыльцы можжевельника изучали методом ВЭЖХ с использованием ВЭЖХ-системы Nexera XR (Shimadzu, Япония).

\section{Световая микроскопия}

Макростробилы в период рецептации фиксировали в уксусном алкоголе. Весь фик- 
сированный материал промывали и хранили до использования в 70\%-ном этаноле. Микротомные срезы толщиной 8-10 мкм окрашивали метиловым зеленым - пиронином G. Просмотр и фотографирование изображений выполняли при помощи лабораторного микроскопа AxioScope A1 (Carl Zeiss, Германия) в комплекте с цифровой фотокамерой Canon G10. Редактирование изображений производили при помощи лицензионной программы AxioVision LE Release 4.8.1. Препарирование семязачатков проводили под бинокулярным микроскопом МБС-10 (Лыткарино, Россия). Временные препараты окрашивали 0,25\%-ным водным раствором сафранина. Фотографирование и редактирование изображений проводили при помощи видеоокуляра Pro-MicroScan 5888 (Oplenic Optronics) и лицензионного программного обеспечения ScopePhoto 3.0.

\section{Результаты и обсуждение}

Пьльцевой режим

Пыльцевой режим в природных популяциях можжевельника изучали в северной тайге (Архангельская область) в 2007, 2010 и 2016 гг.

Onblm 2007 г. Опытный участок - двухъярусный древостой. Состав первого яруса 10Лц, второго - 8Е2Б. Средний возраст деревьев первого яруса около 350 лет, средняя высота 36 м, средний диаметр 80 см. Суммарная полнота обоих ярусов 0,5 . Сомкнутость можжевелового подлеска около 40 \%, характер размещения его - равномерный, местами он образует труднопроходимые заросли. Старые растения представляют стланиковую форму. У наиболее крупных особей диаметр у шейки корня превышает 30 см. Точно их возраст определить не представляется возможным, поскольку все они поражены сердцевинной гнилью. Приблизительно он равен возрасту лиственницы. Возобновление преимущественно вегетативное, корневой порослью (отводками). По половому признаку в составе можжевелового подлеска количественно доминируют женские особи, доля мужских особей не превышает $15 \%$.

С 28 июня установилась довольно жаркая (до $30{ }^{\circ} \mathrm{C}$ ) сухая погода, сохранившаяся до 4 июля, после чего наступило резкое похолодание и пошли дожди. Пыление единичных деревьев можжевельника началось 1 июля, массовое пыление наблюдалось 3 июля и продолжалось оно всего несколько часов (рис. 1). После наступления дождливого периода пыление можжевельника практически полностью прекратилось.

Суммарное количество уловленной пыльцы за весь период пыления можжевельника составило 6,84 пыльцевых зерна на 1 мм² регистрирующей поверхности. Высокие концентрации пыльцы в воздухе наблюдались в течение очень короткого промежутка времени: более 80 \% всего количества пыльцы было уловлено в течение 2 ч, почти 90 \% - в течение 4 ч. Хотя весь период пыления можжевельника составил около недели, концентрации его пыльцы в воздухе, за исключением этого очень короткого промежутка, были крайне низкими.

Onblm 2010 2. Опытный участок - редкостойный ельник, граничащий с верховым болотом, с довольно густым (проективное покрытие около 30 \%) подлеском из можжевельника. Средний возраст можжевельников около 100 лет. Соотношение мужских и женских особей примерно 1:1.

К концу июня установилась умеренно теплая, временами дождливая погода. Слабое пыление единичных мужских особей можжевельника началось 26 июня, однако концентрации пыльцы в воздухе в это время были крайне низкими. Массовое пыление на- 


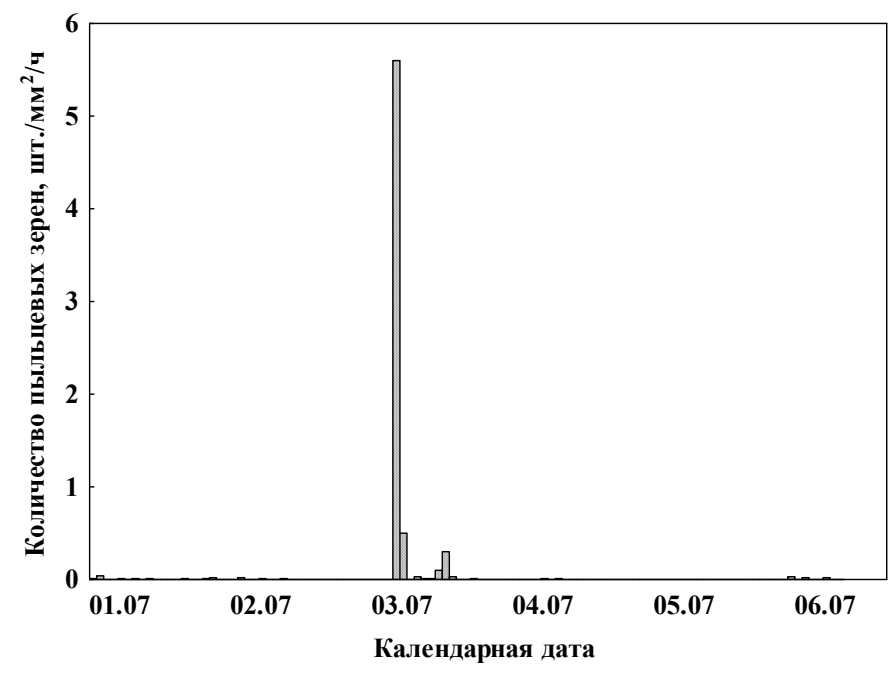

A

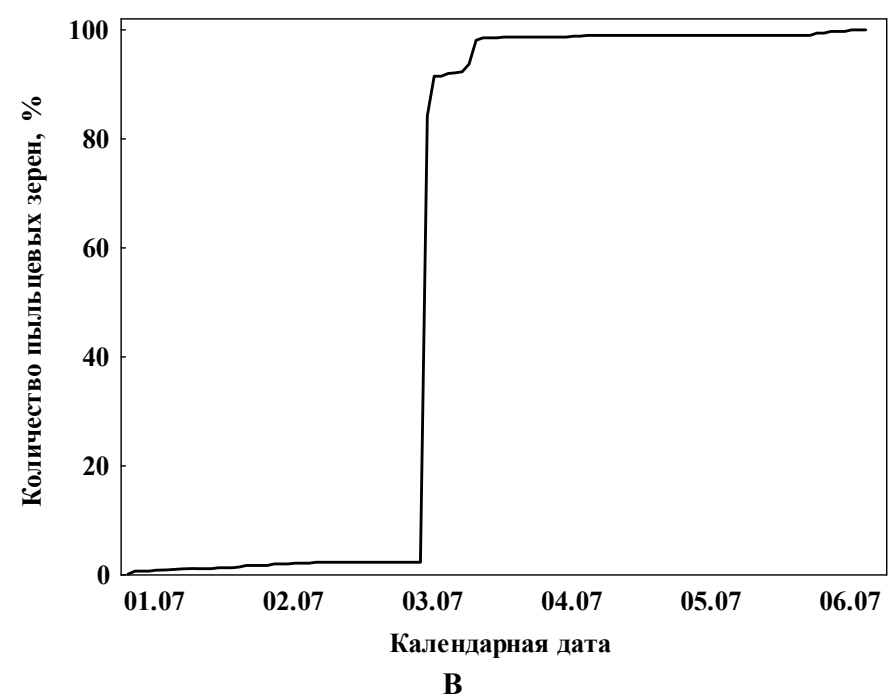

Рис. 1. Пыльцевой режим в природной популяции можжевельника в 2007 г.: a - гистограмма; b кумулята

Fig. 1. The pattern of pollen dispersion in the natural juniper population in 2007: $a$ - histogram; $b$ - cumulative curve

блюдалось на следующий день - 27 июня, и пришлось на ранние послеполуденные часы. К вечеру того же дня пыление можжевельника практически полностью прекратилось. Суммарное количество пыльцы за весь период пыления можжевельника составило 19,64

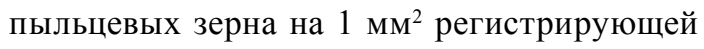
поверхности. Однако временной отрезок высокой концентрации пыльцы в воздухе (рис. 2).

$$
-54-
$$

был очень короткий: 95,7 \% всего количества пыльцы было уловлено в течение 3,6 ч, 98,2 \% - в течение 6 ч. Весь период пыления можжевельника составил около двух суток, однако концентрации его пыльцы в воздухе, за исключением этого очень короткого промежутка времени, приходящегося на послеполуденные часы, были крайне низкими 

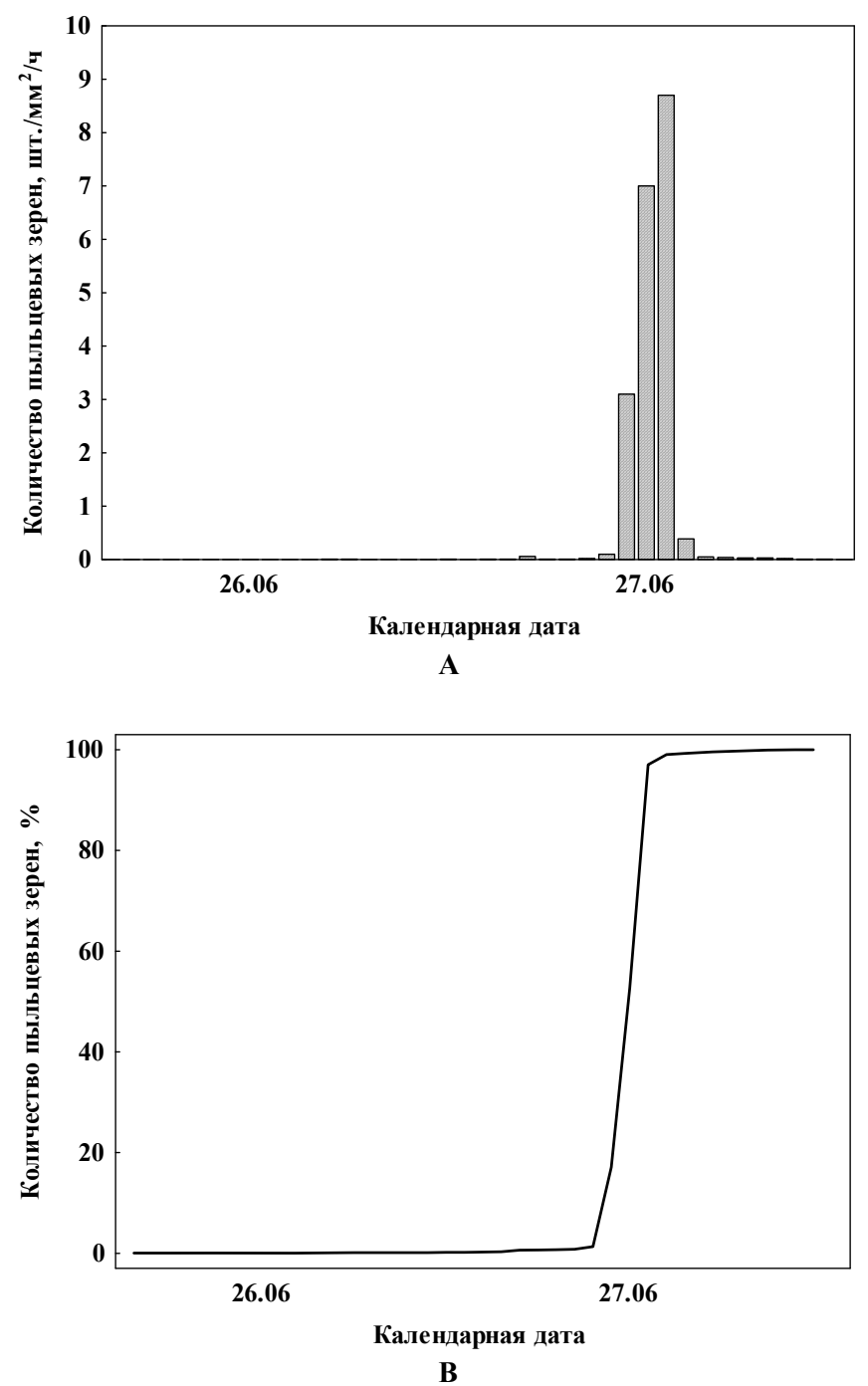

Рис. 2. Пыльцевой режим в природной популяции можжевельника в 2010 г.: a - гистограмма; b кумулята

Fig. 2. The pattern of pollen dispersion in the natural juniper population in 2010: $a$ - histogram; $b$ - cumulative curve

Onblm 2016 г. Опытный участок - широкая долина ручья с пологими склонами, густо заросшими можжевельниками. Растения кустообразной формы, сильно переплетенные в комлевой части, высотой 1,5-2,5 $(3,5)$ м. Возраст растений около 200 лет. Соотношение мужских и женских особей примерно одинаково, с небольшим преобладанием доли мужских (в среднем, 54,7 и 45,3\%, соответственно).
Пыление у можжевельника началось 14 июня в $12^{\underline{00}}$ и закончилось в тот же день в $22^{4 \underline{48}}$. Продолжительность пыления составила 11 ч. Массовое пыление продолжалось с $13^{12}$ до $18 \frac{00}{}$, т.е. не более 5 ч (рис. 3). В течение этого времени было уловлено 97,25 \% от общего количества пыльцы. Суммарное количество пыльцы за весь период пыления можжевельника составило 16,81 пыльцевых зерна на 1 мм² $^{2}$ регистрирующей поверхности. 


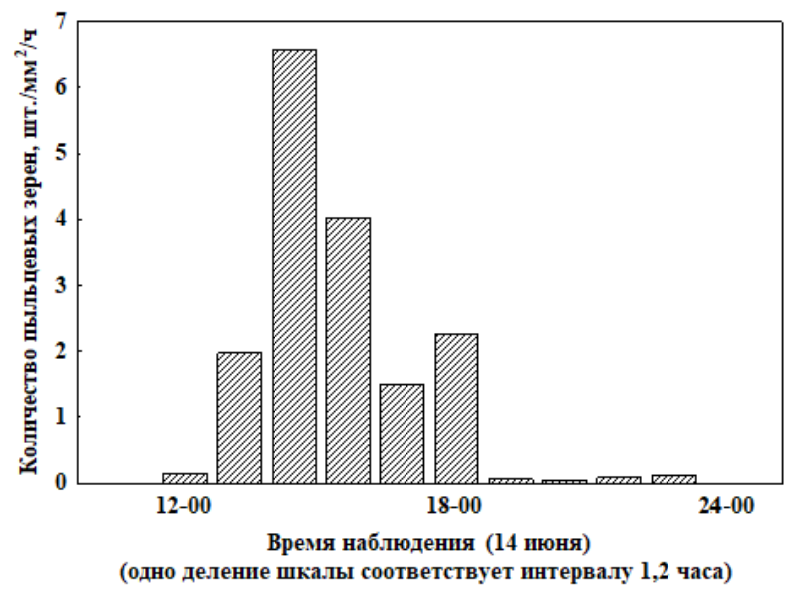

A

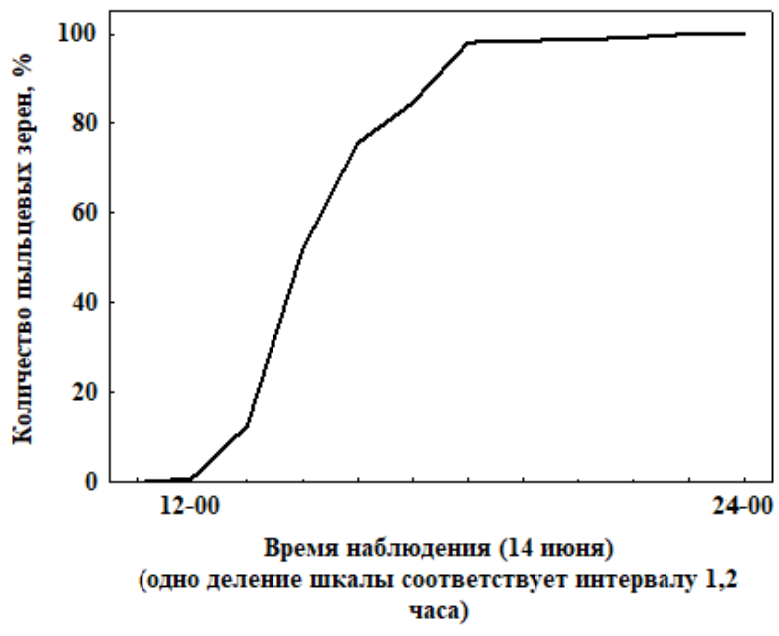

B

Рис. 3. Пыльцевой режим в природной популяции можжевельника в 2016 г.: a - гистограмма; b кумулята

Fig. 3. The pattern of pollen dispersion in the natural juniper population in 2016: $a$ - histogram; $b$ - cumulative curve

Пыльцевой режим у можжевельника отличается от общей схемы пыльцевого режима у лесообразующих хвойных видов, у которых общая продолжительность периода пыления может растягиваться на несколько недель (Некрасова, 1983) и для которых характерен синусоидальный тип кривой распределения плотности пыльцевого потока с максимумами в полуденные и минимумами в ночные часы (Сурсо, 2009). У можжевельника такая кривая представлена всего одним максимумом за счет очень короткого (не более 4-6 ч) периода массового пыления, приходящегося на полуденные и ранние предвечерние часы, в течение одних календарных суток. Эта закономерность сохраняется из года в год и не зависит ни от погодных условий в период рецептации, ни от особенностей места произрастания можжевельника.

$$
-56-
$$


Таблица 1. Аэродинамические свойства пыльцы хвойных видов (Сурсо, 2009)

Table 1. The aerodynamic properties of the pollen of coniferous species (Surso, 2009)

\begin{tabular}{|c|c|c|c|c|c|}
\hline \multirow{2}{*}{ Порода } & \multirow{2}{*}{ 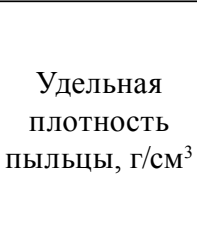 } & \multicolumn{2}{|c|}{$\begin{array}{c}\text { Размеры } \\
\text { среднестатистического } \\
\text { пыльцевого зерна }\end{array}$} & \multirow{2}{*}{$\begin{array}{c}\text { Минимальная } \\
\text { скорость } \\
\text { свободного } \\
\text { падения, см/c* }\end{array}$} & \multirow{2}{*}{$\begin{array}{c}\text { Максимальная } \\
\text { скорость } \\
\text { осаждения } \\
\text { в этиловом } \\
\text { эфире, см/с** }\end{array}$} \\
\hline & & мacca, г & $\begin{array}{c}\text { площадь } \\
\text { поверх- } \\
\text { ности, мм² }\end{array}$ & & \\
\hline Pinus sylvestris & 0,335 & $0,405 \cdot 10^{-7}$ & $0,145 \cdot 10^{-1}$ & 2,8 & 0,56 \\
\hline Picea abies x $P$. obovata & 0,239 & $0,184 \cdot 10^{-6}$ & $0,481 \cdot 10^{-1}$ & 2,7 & 0,43 \\
\hline Larix sibirica & 0,548 & $0,174 \cdot 10^{-6}$ & $0,225 \cdot 10^{-1}$ & 9,4 & 1,37 \\
\hline Juniperus communis & 0,610 & $0,464 \cdot 10^{-8}$ & $0,187 \cdot 10^{-2}$ & 3,6 & 0,63 \\
\hline
\end{tabular}

* Определялась по верхней границе пыльцевого столбика.

** Определялась по нижней границе пыльцевого столбика.

Пыльцевая продуктивность мужских растений можжевельника, произрастающих в компактных биогруппах на хорошо освещенных склонах, довольно высокая и составляет, по нашим данным, $10^{11}-10^{13}$ пыльцевых зерен на 1 га. Это сопоставимо с пыльцевой продуктивностью таких хвойных видов, как ель $\left(10^{12}-10^{13}\right.$ шт./га) и сосна $\left(10^{13}-10^{14}\right.$ шт./га) (Сурсо, 2009). По своим аэродинамическим характеристикам пыльца можжевельника приближается к тем видам, пыльцевые зерна у которых имеют воздушные мешки (табл. 1).

Следовательно, столь короткий период массового пыления у можжевельника можно объяснить лишь тем, что его разлетающаяся пыльца стартует с очень небольшой высоты. Поэтому почти вся масса производимой пыльцы оседает поблизости от модулятора. Перенос сколько-нибудь значимых объемов пыльцы на большие расстояния у можжевельника маловероятен в силу того же обстоятельства.

\section{Механизм опьления}

Ко времени опыления семязачатки можжевельника дифференцированы на интегумент и нуцеллус (рис. $4 b$ ). В халазальной части нуцеллуса в окружении клеток нуцеллярного тапетума обособляется одна или несколько материнских клеток макроспор. В период рецептации микропилярный канал служит для подъема секреторной жидкости к верхнему кончику микропилярного входа семязачатка. Пыльца улавливается секреторной каплей (рис. $4 a$ ), прилипая к ее поверхности. Ретракция секреторной жидкости обеспечивает транслокацию пыльцевых зерен от микропилярного кончика интегумента к верхушке нуцеллуса, где пыльцевые зерна сбрасывают экзину и прорастают. Сразу после опыления микропилярный канал семяпочки в субнуцеллярной зоне почти полностью смыкается вследствие поперечного вытягивания клеток, слагающих внутреннюю поверхность интегумента (рис. 4c). Очень узкое отверстие в микропилярном канале сохраняется на зиму. Окончательная изоляция мегагаметофитов происходит на следующий год после начала формирования «шишкоягоды», когда клетки внутренних поверхностей смежных мегаспорофиллов смыкаются в проксимальной части путем зубчатой «сшивки».

\section{Опьлительная капля}

Важную роль в процессе опыления (улавливание пыльцы и транслокация пыльцевого зерна к нуцеллусу семязачатка) у 


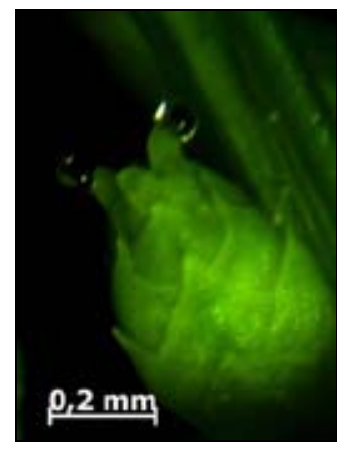

A

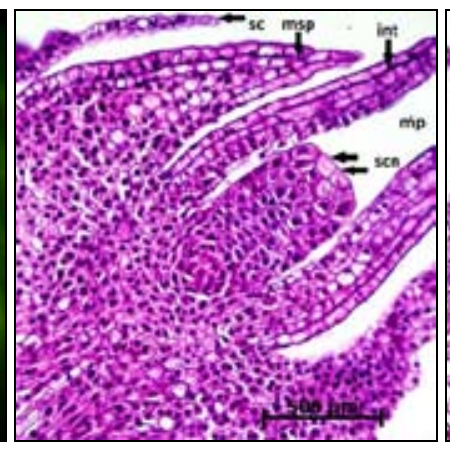

B

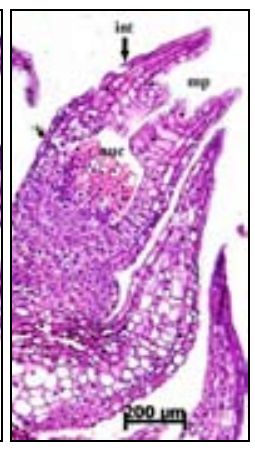

C

Рис. 4. Семязачатки можжевельника непосредственно перед (a, b) и вскоре после (c) опыления (микротомные срезы окрашены метиловым зеленым - пиронином G): int - интегумент, пuс - нуцеллус, $\mathrm{mp}$ - микропиле, sc - покровные чешуи семязачатка, msp - мегаспорофилл, scn - секреторные клетки нуцеллуса

Fig. 4. Juniper ovules immediately before ( $a$ and $b$ ) and soon after (c) pollinations (microtome sections are stained with methyl green - pyronine G): int - integument, nuc - nucellus, mp - micropyle, sc - integumentary scales of ovule, msp - megasporophyll, scn - secretory cells of nucellus

Juniperus играет опылительная капля, скапливающаяся на верхушке микропиле семязачатка в период рецептации. Дж. Оуэнс с соавт. (Owens et al., 1998) полагают, что опылительная капля у большинства хвойных секретируется апикальными клетками нуцеллуса, но, возможно, также клетками тканей мегагаметофита и интегумента. У можжевельника, на наш взгляд, вероятнее всего, секрет вырабатывается несколькими клетками апикальной зоны нуцеллуса. На pис. $4(b, c)$ эти клетки можно идентифицировать по отсутствию в них ядер. Впоследствии эти клетки лизируют, освобождая место для формирования пыльцевой подушки нуцеллуса. Опылительная капля у можжевельника является многофункциональной. Овулярный секрет не только служит для улавливания пыльцевых зерен, но и участвует в процессе узнавания, предотвращает преждевременное сбрасывание экзины, ингибирует развитие микрофлоры и способствует росту и развитию пыльцевых трубок на начальных стадиях прорастания пыльцы.
Опылительная капля реагирует на внешние раздражители. Эта реакция избирательна, что подтверждается результатами экспериментов (табл. 2 и 3 ).

При опылении рецептивных семязачатков пыльцой можжевельника полная ретракция экссудационного секрета завершилась менее чем за 4 ч. При опылении чужеродной пыльцой значительная часть опылительных капель продолжала оставаться на поверхности семязачатков более 16 ч. При отсутствии опыления экссудационная деятельность микропилярной зоны семязачатков продолжалась не менее 60 ч. Размеры капли при этом увеличились до максимальных, в среднем на 40 \%. Наблюдались частые случаи слияния капель двух или всех трех семязачатков в одну общую для макростробила крупную каплю. Через 90 ч на кончиках большинства семязачатков наблюдались уже довольно мелкие капли, многие семязачатки были без капель, крупные капли сохранились лишь на единичных семязачатках. Через 120 ч у всех неопыленных семязачатков произошла 
Таблица 2. Динамика экссудации секреторной жидкости можжевельника в опыте 2015 г. (диаметр опылительной капли: над чертой - мкм, под чертой - \% от исходного значения)

Table 2. The dynamics of exudation of juniper secretory liquid in the experiment of 2015 (diameter of pollination drop: above the line $-\mu \mathrm{m}$, below the line $-\%$ of the original value)

\begin{tabular}{|l|c|c|c|c|c|c|c|}
\hline \multirow{2}{*}{ Вариант опыления } & \multicolumn{7}{|c|}{ Количество часов с момента опыления } \\
\cline { 1 - 8 } & 0 & 4 & 16 & 44 & 60 & 90 & 120 \\
\hline Пыльца можжевельника & $\underline{327,8}$ & $\underline{0}$ & $\underline{0}$ & $\underline{0}$ & $\underline{0}$ & $\underline{0}$ & $\underline{0}$ \\
\cline { 2 - 5 } Пыльца сосны & 100 & 0 & 0 & 0 & 0 & 0 & 0 \\
Без опыления & $\underline{323,7}$ & $\underline{243,1}$ & $\underline{31,6}$ & $\underline{0}$ & $\underline{0}$ & $\underline{0}$ & $\underline{0}$ \\
& 100 & 75,1 & 9,8 & 0 & 0 & 0 & 0 \\
& $\underline{324,3}$ & $\underline{337,4}$ & $\underline{357,1}$ & $\underline{435,0}$ & $\underline{457,1}$ & $\underline{39,7}$ & $\underline{0}$ \\
\hline
\end{tabular}

Таблица 3. Динамика экссудации секреторной жидкости можжевельника в опыте 2016 г. (диаметр опылительной капли: над чертой - мкм, под чертой - \% от исходного значения)

Table 3. The dynamics of exudation of juniper secretory liquid in the experiment of 2016 (the diameter of the pollination drop: above the line $-\mu \mathrm{m}$, below the line $-\%$ of the original value)

\begin{tabular}{|c|c|c|c|c|c|c|c|}
\hline \multirow{2}{*}{ Вариант опыления } & \multicolumn{7}{|c|}{ Количество часов с момента опыления } \\
\hline & 0 & 6 & 22 & 48 & 72 & 100 & 120 \\
\hline Пыльца можжевельника & $\frac{347,5}{100}$ & $\frac{177,5}{51,1}$ & $\underline{0}$ & $\underline{0}$ & $\underline{0}$ & $\underline{0}$ & $\frac{0}{0}$ \\
\hline Силикагель (25-40 мкм) & $\frac{290,0}{100}$ & $\frac{232,5}{80,2}$ & $\frac{57,5}{19,8}$ & $\frac{0}{0}$ & $\frac{0}{0}$ & $\underline{0}$ & $\underline{0}$ \\
\hline Силикагель (63-100 мкм) & $\frac{267,5}{100}$ & $\frac{257,5}{96,3}$ & $\frac{107,5}{40,2}$ & $\frac{37,5}{14,0}$ & $\frac{0}{0}$ & $\frac{0}{0}$ & $\frac{0}{0}$ \\
\hline Силикагель (160-200 мкм) & $\frac{352,5}{100}$ & $\frac{317,5}{90,1}$ & $\frac{300,0}{85,1}$ & $\frac{295,0}{83,7}$ & $\frac{77,5}{22,0}$ & $\frac{0}{0}$ & $\frac{0}{0}$ \\
\hline Без опыления & $\frac{345,0}{100}$ & $\frac{375,0}{108,7}$ & $\frac{275,0}{79,7}$ & $\frac{262,5}{76,1}$ & $\frac{260,0}{75,4}$ & $\frac{150,0}{43,5}$ & $\frac{0}{0}$ \\
\hline
\end{tabular}

полная ретракция секреторной жидкости. Опыты по искусственному опылению секреторной капли силикагелями с частицами различного диаметра показали, что их размер влияет на продолжительность экссудации и скорость ретракции секреторной жидкости. Чем крупнее частицы силикагеля, тем дольше задерживается ретракция опылительной капли. Крупные частицы (диаметром более 40 мкм) не могут проникнуть в узкий микропилярный канал семязачатка и скапливаются у его входа снаружи. Частицы силикагеля, близкие по размерам к пыль- цевым зернам можжевельника, свободно проникают внутрь семязачатка, втягиваясь туда вместе с секреторной жидкостью. Приведенные данные подтверждают результаты экспериментов С. Мугнайни с соавт. по искусственному опылению секреторной капли силикагелями с размерами частиц разного диаметра (Mugnaini et al., 2007a). В своих исследованиях эти авторы также доказали влияние размера частиц силикагелей на продолжительность экссудации и скорость ретракции секрета рецептивных семязачатков можжевельника. 
В составе летучих фракций органических соединений опылительной капли можжевельника выявлено около 40 веществ, принадлежащих к различным классам. Процентное соотношение этих фракций составляет: алканы - 33,79 \%, монотерпены - 0,29\%, тритерпены - 16,97\%, сесквитерпеновые спирты - 1,33\%, сложные эфиры - 18,41 \%, карбоновые кислоты - 1,81\%, амиды карбоновых кислот $-8,81 \%$. Следует отметить высокое содержание сквалена (соединения тритерпенового ряда, принадлежащего к группе каротиноидов) - 14,85 \%, а также сложных эфиров, в том числе эфиров фталевой $(12,07 \%)$ и трифторуксусной (октатриаконтила трифлуороацетата, принадлежащего к флуорохромам - 8,23 \%) кислот.

В состав сахаров опылительной капли можжевельника входят только два моносахарида: глюкоза (65,8 \%) и галактоза (34,2 \%) (табл. 4). Анализ аминокислотного состава секрета показал, что в нем преобладают L-аргинин (25,5 \%), L-аспарагиновая (20,7 \%) и L-глутаминовая (15,1\%) кислоты. Отмечено также наличие L-цистеина (3,8 \%), глицина (1,9\%), L-гистидина (2,8 \%), L-лейцина (7,5 \%), L-лизина (2,8 \%), L-метионина (2,8 \%), $\mathrm{L}$-пролина (3,8 \%), L-серина (7,6 \%) и L-валина (5,7 \%) (табл. 5).

Однако состав аминокислот, как и сахаров, в секреторной капле беднее, а общее со- держание на порядок ниже по сравнению с пыльцой.

Следует отметить, что исследований химического состава опылительной капли голосеменных растений крайне мало, и он, в отличие от нектара цветковых (Dumas et al., 1988), все еще остается изученным недостаточно полно. Известно о наличии в нем монои дисахаридов, аминокислот, органических кислот (Nepi et al., 2009). Протеомные исследования свидетельствуют о присутствии в нем белков, большинство из которых не идентифицировано (Poulis et al., 2005; Wagner et al., 2007). Сложный химический состав опылительной капли свидетельствует о ее многофункциональности и заслуживает дальнейшего изучения.

\section{Морфология пыльиь}

Особенности строения и биометрические параметры пыльцевых зерен определяют их аэродинамические свойства (Schwendemann et al., 2007). Пыльцевые зерна можжевельника одноклеточные и, по сути, являются микроспорами, не проросшими в микрогаметофит. Пыльцевые зерна почти правильной сферической формы, без воздушных мешков, имеют одну функциональную пору (дистальную апертуру), которая у сухой пыльцы прикрыта крышечкой (рис. 5a). Поверхность сэкзины мелко гранулированная, покрыта многочис-

Таблица 4. Состав и относительное содержание сахаров в пыльце и овулярном секрете можжевельника обыкновенного

Table 4. The composition and relative contents of sugars in pollen and ovular secretion of juniper

\begin{tabular}{|c|c|c|c|c|}
\hline \multirow{2}{*}{ Проба } & \multicolumn{3}{|c|}{ Содержание сахаров (над чертой - мкг/мл, под чертой - \%) } \\
\cline { 1 - 5 } & арабиноза & галактоза & ксилоза & глюкоза \\
\hline \multirow{2}{*}{ Пыльца } & $\frac{206,888}{20,8}$ & $\frac{562,498}{56,6}$ & $\frac{13,651}{1,4}$ & $\frac{210,748}{21,2}$ \\
Капля & $\underline{0}$ & $\underline{4,860}$ & $\underline{0}$ & $\frac{9,366}{65,8}$ \\
\hline
\end{tabular}


Таблица 5. Состав и относительное содержание аминокислот в пыльце и овулярном секрете можжевельника обыкновенного (над чертой - \% от общего количества, под чертой - относительно содержания в пыльце)

Table 5. The composition and relative contents of amino acids in pollen and ovular secretion of juniper (above the line $-\%$ of the total, below the line - relative to the content in pollen)

\begin{tabular}{|c|c|c|}
\hline Наименование & Пыльца & Секреторная капля \\
\hline L-Аланин & 5,9 & 0 \\
\hline L-Аргинин & 3,8 & $\frac{25,5}{0,71}$ \\
\hline L-Aспарагиновая кислота & 13,7 & $\frac{20,7}{0,16}$ \\
\hline L-Цистеин & 0,7 & $\underline{\frac{3,8}{0,57}}$ \\
\hline L-Глутаминовая кислота & 17,9 & $\frac{15,1}{0,09}$ \\
\hline Глицин & 5,7 & $\frac{1,9}{0,04}$ \\
\hline L-Гистидин & 2,5 & $\frac{2,8}{0,12}$ \\
\hline L-Изолейцин & 4,2 & 0 \\
\hline L-Лейцин & 7,5 & $\frac{7,5}{0,11}$ \\
\hline L-Лизин & 7,6 & $\frac{2,8}{0,04}$ \\
\hline L-Метионин & 1,0 & $\frac{2,8}{0,3}$ \\
\hline L-Фенилаланин & 3,9 & 0 \\
\hline L-Пролин & 2,7 & $\frac{3,8}{0,15}$ \\
\hline L-Серин & 7,3 & $\frac{7,6}{0,11}$ \\
\hline L-Tреонин & 6,6 & 0 \\
\hline L-Tирозин & 3,8 & 0 \\
\hline L-Валин & 5,2 & $\frac{5,7}{0,12}$ \\
\hline
\end{tabular}

ленными орбикулами диаметром 450-650 нм (рис. 5). Орбикулы снабжены шипиками, при помощи которых они непрочно удерживаются на поверхности пыльцевого зерна (рис. 5e). При гидратации пыльцевых зерен часть орбикул отрывается, образуя на поверхности экзины перфорации (рис. 5d).

По своим размерам и морфологии орбикулы удивительным образом схожи с вирусами. В этом случае геном вируса должен быть встроен в геном можжевельника, подобно вирусу герпеса. Исследование химического состава орбикул с помощью сканирующего электронного микроскопа показало наличие в них азота. Возможно, в орбикулах может присутствовать ДНК, и в этом случае можно идентифицировать принадлежность вируса. С этой целью водную суспензию зрелой пыльцы можжевельника пропускали на виброшейкере сквозь сито с отверстиями 


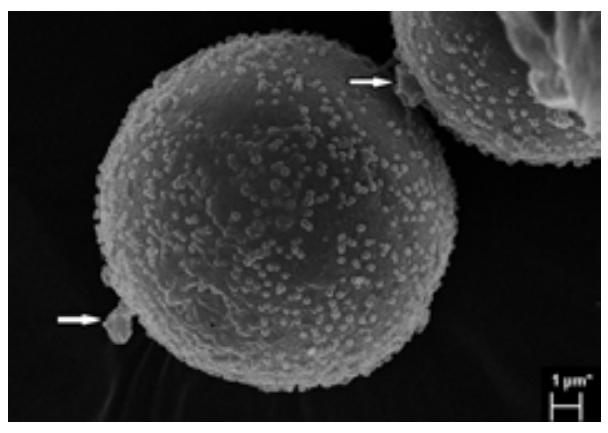

A

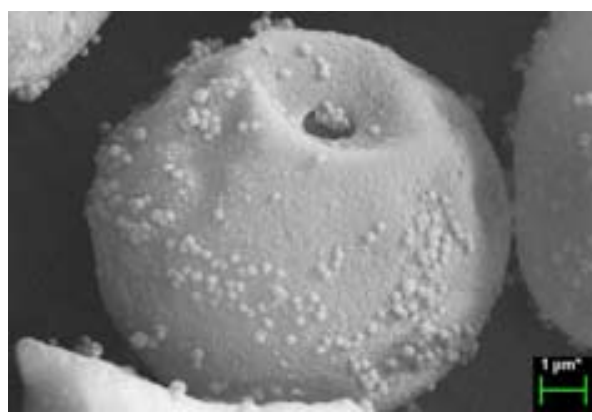

C

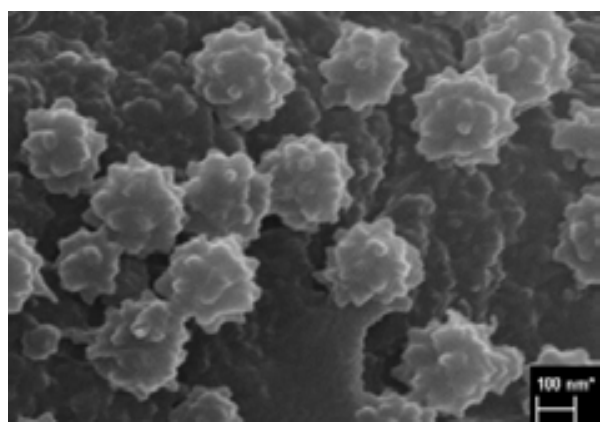

E

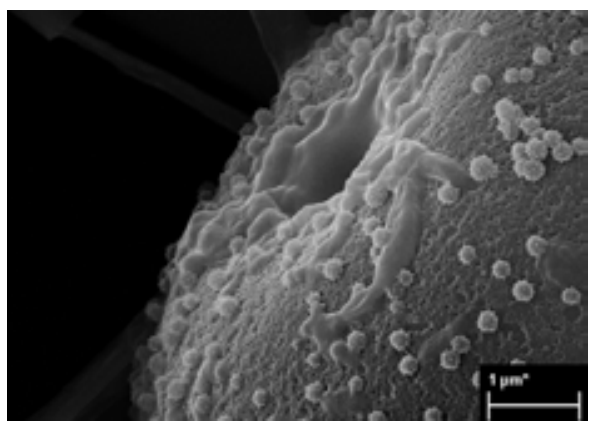

B

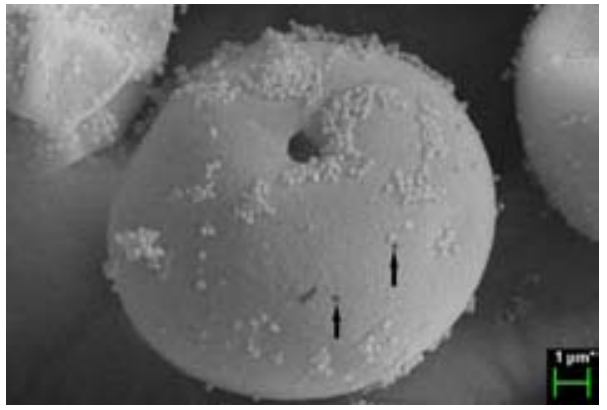

D

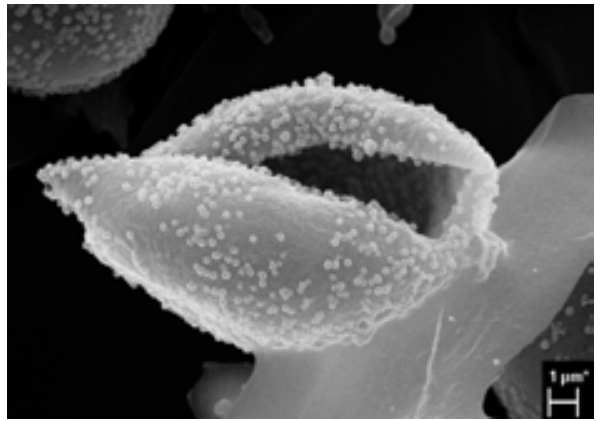

F

Рис. 5. Общий вид и поверхность экзины пыльцевых зерен можжевельника: а - крышечки, закрывающие функциональную пору (показаны стрелками); $\mathrm{b}$ - функциональная пора и орбикулы на поверхности экзины; с - скопление орбикул в зоне функциональной поры; d - перфорации, образовавшиеся на поверхности экзины пыльцевого зерна в результате отрывания орбикул (показаны стрелками), видна тень от одной из оторвавшихся орбикул; е - орбикулы на поверхности экзины снабжены шипиками; fсброшенная экзина (на внешней поверхности эндонэкзины просвечивают орбикулы, прикрепленные к наружной поверхности сэкзины)

Fig. 5. General appearance and surface of the exine of juniper pollen grains: a - caps closing the functional pore (arrows); $b$ - functional pore and orbicules on the surface of the exine; $c$-aggregate of orbicules at the functional pore; $\mathrm{d}$ - perforations on the surface of the exine of pollen grains resulting from detachment of orbicules (arrows), the shadow of one of the detached orbicules is visible; $\mathrm{e}$ - orbicules on the surface of the exine have barbs; $f$ the shed exine (on the outer surface of endonexine, the orbicules attached to the outer surface of sexine show through) 
диаметром 20 мкм. Полученную суспензию замораживали в жидком азоте и высушивали лиофильно. Образец ресупензировали в $\mathrm{diH} 2 \mathrm{O}$ и подогревали до $65^{\circ} \mathrm{C}$. При добавлении интеркалирующего красителя SibrGreen зеленая флюоресценция не наблюдалась, что говорит об отсутствии свободной ДНК/РНК на поверхности биоматериала. Суспензию разделяли на две части. Из первой части выделяли ДНК коммерческим набором DNeasy Plant Mini Kit (QIAGEN, Германия), в соответствии с рекомендациями производителя. На выходе наблюдалась нулевая концентрация ДНК. Вторую часть суспензии подвергли стандартному выделению ДНК, используя фенол-хлороформную экстракцию. К 100 мкл суспензии было добавлено 200 мкл смеси фенол (рН 8,0): хлороформ (1:1). Осадок растворился. После центрифугирования осадок не наблюдался. Супернатант (вода + теоретически растворенная ДНК) был отобран в чистую пробирку, и к нему добавили равный объем изопропанола для осаждения ДНК. Образец выдерживали в течение суток при минус $20^{\circ} \mathrm{C}$ для наиболее полного осаждения. По результатам эксперимента следов ДНК в образце не было обнаружено. Таким образом, происхождение орбикул остается невыясненным.

Размеры пыльцевых зерен можжевельника составляют, в среднем, 25-26 мкм и имеют очень низкую индивидуальную и внутрипопуляционную изменчивость $(\mathrm{CV}=2,4-2,5$ \%). По мнению Г.М. Козубова (1974), такая низкая изменчивость характерна для всех спорогенных органов и тканей хвойных. Распределение пыльцевых зерен по размерам приближается к нормальному. У можжевельника обыкновенного, произрастающего в северной тайге, из аномалий отмечены только карликовые и деформированные пыльцевые зерна и крайне редко встречаются гигантские полиплоидные зерна. Общее количество аномалий не превышает $0,1 \%$.

\section{Прорастание пыльцы \\ и рост пыльчевых трубок}

Первые метаморфозы пыльцевого зерна можжевельника после высева на питательную среду происходят в результате гидратации пыльцы. Эти метаморфозы не связаны с прорастанием пыльцевого зерна в пыльцевую трубку, а обусловлены сбрасыванием экзины. Подробное описание этого процесса впервые было дано Е. Дьюо (Duhoux, 1982). Ниже даются лишь небольшие уточнения и дополнения к этому исследованию.

Процедура сбрасывания экзины протекает весьма динамично. При гидратации пыльцы вода осмотическим путем всасывается через функциональную пору внутрь пыльцевого зерна. Между внутренней поверхностью эндонэкзины и внутренней интиной микроспоры (будущей стенкой пыльцевой трубки) образуется кольцо (водяной слой). Внешняя граница этого кольца отграничена от внутренней поверхности эндонэкзины элементарной полупроницаемой мембраной. В результате образуется гидрофильная капсула, которая очень быстро увеличивается в объеме и со все возрастающим усилием своей стенкой давит на оболочку пыльцевого зерна. Под растущим тургором стенки быстро увеличивающей свой объем гидрофильной капсулы экзина пыльцевого зерна вскрывается двумя равными створками и сбрасывается (рис. $6 a$ ). Гидрофильная капсула начинает выходить через функциональную пору, и после того, как створки оболочки пыльцевого зерна раздвинутся достаточно широко, экзина очень быстро сползает с гидрофильной капсулы. Диаметр дистальной апертуры пыльцевого зерна можжевельника намного меньше диаметра гидрофильной капсулы с находящейся 


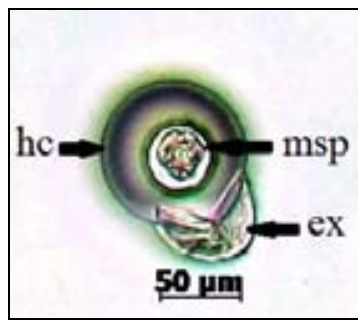

A

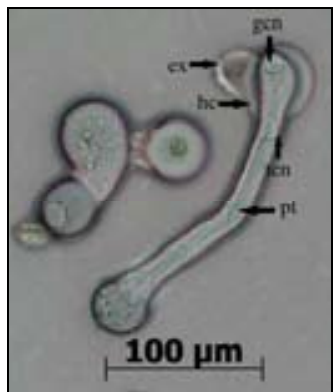

D

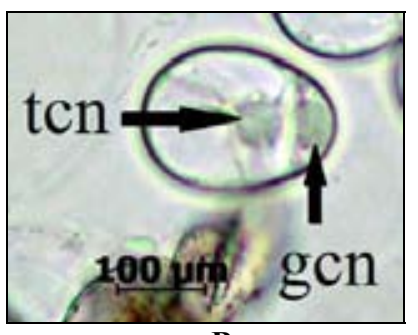

B

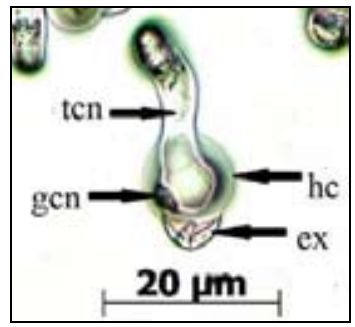

C

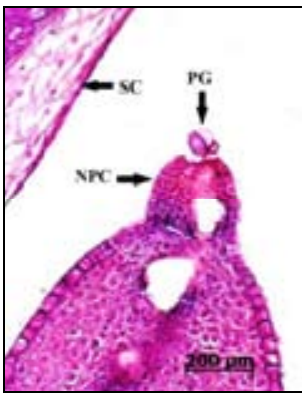

E

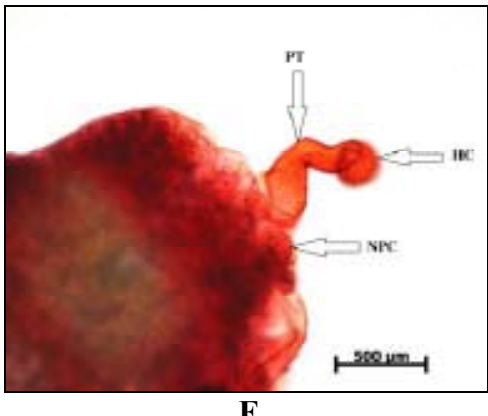

F

Рис. 6. Прорастание пыльцы можжевельника обыкновенного in vitro (a-d) and in vivo (e, f): а - образование гидрофильной капсулы и сбрасывание экзины пыльцевого зерна (стадия 1); b - двухклеточный микрогаметофит (стадия 2); с-пыльцевая трубка на стадии 3 (видна сброшенная экзина, кончик пыльцевой трубки выходит из гидрофильной капсулы, не прорывая ее стенки); $\mathrm{d}$ - сформировавшаяся пыльцевая трубка, гидрофильная капсула сохранилась; е - пыльцевое зерно на поверхности пыльцевой подушки нуцеллуса (экзина вскрылась двумя створками, видна непроросшая микроспора); $\mathrm{f}$ - дистальный кончик пыльцевой трубки незадолго до оплодотворения (спустя 13 месяцев после опыления видна сохранившаяся гидрофильная капсула). Пыльца проращивалась на агаровой среде с добавлением сахарозы (c, d) и в $d \mathrm{H}_{2} \mathrm{O}$ методом «висячей капли» $(\mathrm{a}, \mathrm{b})$. Микротомный препарат семязачатка, окрашивание метиловым зеленым - пиронином G (e). Семязачатки препарировались и затем окрашивались сафранином (f); a-e проходящий свет, f - отраженный свет, ex - экзина, hc - гидрофильная капсула, msp - микроспора, gcn ядро генеративной клетки, tcn - ядро клетки трубки, pt - пыльцевая трубка, npc - пыльцевая подушка нуцелуса семязачатка, pg - пыльцевое зерно, sc - интегумент (семенная кожура)

Fig. 6. Germination of juniper pollen in vitro (a-d) and in vivo (e, f): a - formation of the hydrophilic capsule and shedding of the exine of the pollen grain (stage 1); b - two-celled microgametophyte (stage 2); $\mathrm{c}$ - the pollen tube at stage 3 (the shed exine is visible, the tip of the pollen tube emerges from the hydrophilic capsule without breaking through its wall); $\mathrm{d}$ - a developed pollen tube, with the hydrophilic capsule preserved; e - pollen grain on the surface of the pollen cushion of nucellus (exine dehisced into two valves, an ungerminated microspore is visible); $\mathrm{f}$ - the distal tip of the pollen tube shortly before fertilization (13 months after pollination, the preserved hydrophilic capsule is visible). Pollen was germinated on agar medium supplemented with sucrose (c, d) and $\mathrm{dH}_{2} \mathrm{O}$ by the hanging drop method $(\mathrm{a}, \mathrm{b})$. The microtome section of ovule stained with methyl green - pyronine $\mathrm{G}$ (e). The ovules were dissected and then stained with safranin (f); a-e - transmitted light, f - reflected light, ex exine, hc - hydrophilic capsule, msp-microspore, gcn - generative cell nucleus, tcn - tube cell nucleus, $\mathrm{pt}$ - pollen tube, npc - pollen cushion of nucellus, $\mathrm{pg}$ - pollen grain, $\mathrm{sc}$ - integument (seed coat)

внутри нее микроспорой. Экзина пыльцевого зерна можжевельника довольно толстая и, по-видимому, достаточно прочная. Вероятно, разрыв экзины во многом обусловлен наличием перфораций, появляющихся в местах прикрепления орбикул после гидратации пыльцевого зерна. Локализация орбикул на поверхности экзины лишена какой-либо упорядоченности. Однако, поскольку гидрофильная капсула представляет шар почти идеальной формы, давление ее стенок равномерное по всей площади внутренней поверхности 
эндонэкзины. Поэтому разрыв экзины происходит в районе дистальной апертуры, при этом края образовавшихся створок получаются идеально ровными. То, что гидрофильная капсула имеет собственную наружную стенку в виде мембраны, подтверждается результатами окрашивания гидратированных пыльцевых зерен можжевельника. Четкие внешние контуры капсулы проявляются при окрашивании водными растворами бенгальского розового, гематоксилина - железо-аммонийных квасцов - хлоралгидрата, йод - калий йод хлоралгидрата, конго красного, сафранина, хромового темно-синего, эриохрома черного и ряда других красителей. Характер флуоресценции гидратированных пыльцевых зерен можжевельника при окрашивании акридиновым оранжевым (условия флуоресценции: режим работы 20 Rhod, эмиссия 575-640 нм) свидетельствует о том, что содержимое капсулы представляет собой слабый электролит неопределенного химического состава.

Прорастанию пыльцы и микрогаметогенезу можжевельника обыкновенного in vitro посвящена серия статей Е. Дьюо (Duhoux, $1972 a, 1972 b, 1974)$. Наши наблюдения служат дополнением к этому исследованию. Прорастание микроспоры в микрогаметофит начинается еще внутри гидрофильной капсулы и связано с профазой первого митоза. После образования двухклеточного микрогаметофита начинается постепенная трансформация его в пыльцевую трубку, которая приобретает сначала овальную, затем туфелькообразную форму, но все еще целиком вмещается в гидрофильную капсулу (рис. 6b). Генеративная клетка остается в дистальной части трубки, прижимаясь к одной из ее боковых стенок, а ядро сифоногенной (клетки-трубки) клетки постепенно перемещается ближе к ее центральной зоне. Постепенно растущий кончик пыльцевой трубки достигает края гидрофильной капсулы и выходит из нее, не прорывая ее стенки (рис. 6c). В культуре in vitro гидрофильная капсула сохраняется в течение всего времени проращивания. При прорастании пыльцы можжевельника in vivo гидрофильная капсула сохраняется в течение всего периода роста пыльцевых трубок, вплоть до момента оплодотворения (рис. 6е). Возможно, тем самым предотвращается подсыхание дистального кончика растущей пыльцевой трубки. С началом роста пыльцевой трубки вокруг ядра сифоногенной клетки осуществляется интенсивный синтез полисахаридов и липидов, которые концентрируются вблизи проксимального кончика трубки. Цитоплазма в дистальной части трубки сохраняет оптическую прозрачность, в дистальном же кончике трубки остается и генеративная клетка микрогаметофита.

\section{Жизнеспособность пьльц̧ь}

Проращивание пыльцы можжевельника in vitro не представляет существенных экспериментальных трудностей. Для проращивания пыльцы можжевельника оптимальны гелеобразные (на основе агара) среды, содержащие сахарозу (табл. 6).

При проращивании пыльцы можжевельника в $d \mathrm{H}_{2} \mathrm{O}$, водных растворах сахарозы или минеральных солей развитие пыльцевой трубки чаще всего заканчивается на стадии «туфельки». На агаро-сахарозных средах продолжительность роста пыльцевых трубок ограничивается лишь динамикой процессов развития микрофлоры, избежать которых сложно из-за естественного фона зараженности пыльцы спорами грибов. При длительном периоде инкубирования формируются длинные (более 200 мкм), довольно массивные пыльцевые трубки, часто с булавовидными утолщениями проксимальных кончиков 
Таблица 6. Жизнеспособность пыльцы можжевельника обыкновенного в северной тайге*

Table 6. The viability of pollen of the common juniper in the Northern taiga

\begin{tabular}{|c|c|c|c|c|}
\hline \multirow[t]{2}{*}{ Состав среды } & \multicolumn{3}{|c|}{$\begin{array}{c}\text { Количество пыльцевых зерен, \% } \\
\text { (над чертой } \mathrm{X} \pm \mathrm{m}_{\mathrm{X}} \text {, под чертой }-\mathrm{CV}, \% \text { ) }\end{array}$} & \multirow{2}{*}{$\begin{array}{l}\text { Длина пыльцевой } \\
\text { трубки, мкм** }\end{array}$} \\
\hline & стадия 1 & стадия 2 & стадия 3 & \\
\hline Дистиллированная вода & $\frac{12,6 \pm 3,3}{55,1}$ & $\frac{2,4 \pm 1,0}{49,7}$ & 0 & - \\
\hline 5\%-ный раствор сахарозы & $\frac{53,3 \pm 6,9}{61,1}$ & $\frac{0,4 \pm 0,2}{51,0}$ & 0 & - \\
\hline $1 \%$-ный агар + 5 \% сахароза & $\frac{35,9 \pm 6,1}{48,5}$ & $\frac{23,6 \pm 4,6}{27,4}$ & $\frac{12,2 \pm 3,7}{17,9}$ & $\frac{65,6 \pm 3,1}{7,5}$ \\
\hline
\end{tabular}

* Для проращивания на средах разного состава использовались одни и те же образцы пыльцы. В каждом варианте опыта процент проросших пыльцевых зерен определялся в 5 повторностях по 100 пыльцевых зерен в каждой из повторностей.

Стадия 1 - пыльцевые зерна образовали гидрофильную капсулу и сбросили экзину, микроспора не проросла в микрогаметофит и остается в центре гидрофильной капсулы; стадия 2 - микроспора проросла в двухклеточный микрогаметофит, формирующаяся пыльцевая трубка овальной или туфелькообразной формы полностью или почти целиком находится внутри гидрофильной капсулы; стадия 3 - сформировалась пыльцевая трубка, проксимальный кончик которой вышел из гидрофильной капсулы.

** Средняя длина пыльцевой трубки определялась по результатам измерений длин всех пыльцевых трубок на 3-й стадии.

(рис. $6 d$ ), что свидетельствует об их высокой энергии роста.

Для определения показателей жизнеспособности пыльцы можжевельника сроки проращивания in vitro должны быть не менее 6-7 дней. Следует отметить, что нет четких критериев, какую пыльцу следует считать проросшей, а какую - нет. Дать точную оценку жизнеспособности пыльцы у видов с длительным периодом формирования пыльцевых трубок и с неравномерным прорастанием довольно затруднительно. Жизнеспособность пыльцы у можжевельника, на наш взгляд, можно приблизительно оценить как сумму всех пыльцевых зерен, сформировавших полноценные пыльцевые трубки длиной в 3-4 диаметра пыльцевого зерна (стадия 3), половины двухклеточных овальных или туфелькообразных гаметофитов (стадия 2) и четверти всех пыльцевых зерен, сбросивших экзину, но не сформировавших двухклеточные гаметофиты (стадия 1), выраженную в процентах от общего количества просмотренных пыльцевых зерен:

$$
\mathrm{L}=0,25 \mathrm{~L}_{1}+0,5 \mathrm{~L}_{2}+\mathrm{L}_{3},
$$

где $\mathrm{L}$ - жизнеспособность пыльцы, \%; $\mathrm{L}_{1}, \mathrm{~L}_{2}$ и $\mathrm{L}_{3}$ - доли (\%) пыльцевых зерен, находящихся на 1, 2 и 3 стадиях прорастания соответственно, от общего количества просмотренных зерен.

Индивидуальная изменчивость показателей жизнеспособности пыльцы всегда высокая или очень высокая. Минимальный объем выборки для определения жизнеспособности пыльцы в исследуемом образце при уровне вероятности безошибочного суждения $\mathrm{P}=0,95$ в случае максимально возможной вариативности признака ( $\mathrm{L}=50$ \%) равен 400-м пыльцевым зернам.

\section{Заключение}

Целью исследований являлось изучение процессов опыления и биологии прораста- 
ния пыльцы у можжевельника обыкновенного. Установлено, что пыльцевой режим в природных популяциях этого вида характеризуется очень коротким (не более 4-6 ч) периодом массового пыления. Важную роль в процессе опыления у Juniperus communis играет опылительная капля, скапливающаяся на верхушке микропиле семязачатка в период рецептации. Опыты по искусственному опылению показали, что опылительная капля активно реагирует на внешние раздражители: продолжительность экссудации и ретракции, а также количество выделяемого овулярного секрета зависят от наличия или отсутствия на поверхности капли частиц, их размеров и, очевидно, их физикохимических свойств. Проведенные исследования подтвердили сложный химический состав опылительной капли у можжевельника, что является косвенным доказательством eе многофункциональности. Функциональные свойства и химический состав опыли- тельной капли заслуживают более глубокого изучения.

Процессы гидратации, предшествующие прорастанию пыльцы, предопределены морфологическими особенностями пыльцевого зерна можжевельника. Эксперименты по проращиванию пыльцы in vitro и наблюдения за развитием пыльцевых трубок in vivo показали, что важную роль в процессах сбрасывания экзины и последующего развития пыльцевой трубки у можжевельника обыкновенного играет гидрофильная капсула, сохраняющаяся в течение всей жизни пыльцевых трубок, вплоть до момента оплодотворения. Установлено, что для проращивания пыльцы можжевельника оптимальны гелеобразные (на основе агара) среды, содержащие сахарозу. По результатам этих экспериментов предложена схема расчета жизнеспособности пыльцы можжевельника при проращивании in vitro.

\section{Исследования выполнены при поддерэке РФФИ (проект № 18-04-00056).}

\section{Список литературы}

Дылис Н.В. (1948) О самоопылении и разносе пыльцы у лиственниц. Доклады АН СССР, 9(4): 673-676 [Dylis N.V. On self-pollination and pollen dispersal in larches. Proceedingsof the USSR Academy of Sciences [Doklady AN SSSR], 9(4): 673-676 (in Russian)]

Козубов Г.М. (1974) Биология плодоношения хвойныхх на Севере. Л., Наука, 135 с. [Kozubov G.M. (1974) Biology of fructification of conifers in the North. Leningrad, Nauka, 135 p. (in Russian)]

Некрасова Т.П. (1983) Пыльца и пыльцевой режим хвойных Сибири. Новосибирск, Наука (Сиб. отд-е), 169 с. [Nekrasova T.P. (1983) Pollen and pollen behavior in Siberian conifers. Novosibirsk, Nauka (Siberian Branch), 169 p. (in Russian)]

Ругузов И.А., Склонная Л.У., Чеботарь А.А. (1992) Об опылительной капле у хвойных. Ботанический журнал, 77(12): 40-52 [Ruguzov I.A., Sklonnaya L.U., Chebotar A.A. (1992) On the pollination drop in conifers. Botanical Journal [Botanicheskij zhurnal], 77 (12): 40-52 (in Russian)]

Ругузова А.И. (2004) Морфо-физиологические особенности формирования пыльцевых зерен и опыления у некоторых видов сем. Cирressaceae. Ботанический журнал, 89(7): 1111-1121 [Ruguzova A.I. (2004) Morphological and physiological peculiarities in formation of pollen grains and

$$
-67-
$$


pollination in some introducted species of Cupressaceae. Botanical Journal [Botanicheskij zhurnal], 89(7): 1111-1121 (in Russian)]

Сурсо М.В. (2009) Пыльцевой режим в хвойных насаждениях Севера. Лесной вестник, 3(66): 33-38 [Surso M.V. (2009) The pollen cloud dynamics in the North European conifer stands. Forestry Bulletin [Lesnoj vestnik], 3(66): 33-38 (in Russian)]

Altintaş D.U., Karakoç G.B., Yilmaz M., Pinar M., Kendirli S.G., Çakan H. (2004) Relationship between pollen counts and weather variables in East-Mediterranean coast of Turkey. Clinical and Developmental Immunology, 11(1): 87-96

Anderson E.D., Owens J.N. (2000) Microsporogenesis, pollination, pollen germination and male gametophyte development in Taxus brevifolia. Annals of Botany, 86(5): 1033-1042

Belmonte J., Canela M., Guardia R., Guardia R.A., Sbai L., Vendrell M., Cariñanos P., Diaz de la Guardia C., Dopazo A., Fernandez D., Gutierres M., Trigo M.M. (1999) Aerobiological dynamics of the Cupressaceae pollen in Spain, 1992-98. Polen, 10(27): 27-38

Bortenschlager S. (1990) Aspects of pollen morphology in the Cupressaceae. Grana, 29(2): $129-138$

Diaz de la Guardia C., Alba F., de Linares C., Nieto-Lugilde D., Lopez Caballero J. (2006) Aerobiological and allergenic analysis of Cupressaceae pollen in Granada (Southern Spain). Journal of Investigational Allergology and Clinical Immunology, 16(1): 24-33

Doyle J. (1945) Developmental lines in pollination mechanisms in the Coniferales. The Scientific Proceedings of the Royal Dublin Society, 24(5): 43-62

Duhoux E. (1972a) Structural growth of the wall of the pollen grain of Juniperus communis (Cupressaceae), growth in vitro during the hydratation phase. Comptes Rendus Des Seanses Hebdomadaires De L'Academie Des Sciences, France, D, 274(20): 2767-2770

Duhoux E. (1972b) Formation of the cell wall of the pollen tube during germination of pollen in Juniperus communis growth in vitro. Comptes Rendus Des Seanses Hebdomadaires De L'Academie Des Sciences, France, D, 274(24): 3238-3241

Duhoux E. (1974) The division of the reproductive cell and the release of its products in the pollen tubes of Juniperus communis and Cupressus arizonica. Revue Generale De Botanique, 81(962/963/964): 193-204

Duhoux E. (1982) Mechanism of exine rupture in hydrated taxoid type of pollen. Grana, 21(1): 1-7

Dumas C., Bowman R.B., Gaude T., Guilly C.M., Heizmann P., Roeckel P., Rougier M. (1988) Stigma and stigmatic secretion reexamined. Phyton, 28(2): 193-200

Fernando D.D., Lazzaro M.D., Owens J.N. (2005) Growth and development of conifer pollen tubes. Sexual Plant Reproduction, 18(4): 149-162

Friedman J., Barrett S.C.H. (2009) Wind of change: new insights on the ecology and evolution of pollination and mating of wind-pollinated plants. Annals of Botany, 103(9): 1515-1527

Gelbart G., von Aderkas P. (2002) Ovular secretions as part of pollination mechanisms in conifers. Annals of Forest Science, 59(4): 345-357

Ianovici N., Panaitescu C.B., Brudiu I. (2013) Analysis of airborne allergenic pollen spectrum for 2009 in Timişoara, Romania. Aerobiologia, 29(1): 95-111

Kurmann M.H. (1994) Pollen morphology and ultrastructure in the Cupressaceae. Acta Botanica Gallica, 141(2): 141-147 
Labandeira C.C., Kvaček J., Mostovski M.B. (2007) Pollination drops, pollen, and insect pollination of Mesozoic gymnosperms. Taxon, 56(3): 663-695

McWilliam J.R. (1958) The role of the micropyle in the pollination of Pinus. Botanical Gazette, 120(2): 109-117

Mugnaini S., Nepi M., Guarnieri M., Piotto B., Pacini E. (2007a) Pollination drop withdrawal in Juniperus communis: response to biotic and abiotic particles. Caryologia, 60(1-2): 182-184

Mugnaini S., Nepi M., Guarnieri M., Piotto B., Pacini E. (2007b) Pollination drop in Juniperus communis: response to deposited material. Annals of Botany, 100(7): 1475-1481

Necib A., Boughediri L. (2016) Airborne pollen in the El-Hadjar town (Algeria NE). Aerobiologia, 32(2): 277-288

Nepi M., von Aderkas P., Wagner R., Mugnaini S., Coulter A., Pacini E. (2009) Nectar and pollination drops: how different are they? Annals of Botany, 104(2): 205-219

Nikkanen T. (2001) Reproductive phenology in a Norway spruce seed orchard. Silva Fennica, 35(1): $39-53$

Nikkanen T., Pakkanen A., Heinonen J. (2002) Temporal and spatial variation in airborne pollen and quality of the seed crop in a Norway spruce seed orchard. Forest Genetics, 9(3): 243-255

Owens J.N., Simpson S.J., Caron G.E. (1987) The pollination mechanism of Engelmann spruce (Picea engelmanii). Canadian Journal of Botany, 65(7): 1439-1450

Owens J.N., Takaso T., Runions C.J. (1998) Pollination in conifers. Trends in Plant Science, 3(12): 479-485

Poulis B.A.D., O'Leary S.J.B., Haddow J.D., von Aderkas P. (2005) Identification of proteins present in the Douglas fir ovular secretion: an insight into conifer pollen selection and development. International Journal of Plant Science, 166(5): 733-739

Puljak T., Mamić M., Mitić B., Hrga I., Hruševar D. (2016) First aerobiological study in Mediterranean part of Croatia (Dalmatia): pollen spectrum and seasonal dynamics in the air of Split. Aerobiologia, 32(4): 709-723

Rogers C.A., Levetin E. (1998) Evidence of long-distance transport of mountain cedar pollen into Tulsa, Oklahoma. International Journal of Biometeorology, 42(2): 65-72

Sabariego S., Cuesta P., Fernández-González F., Pérez-Badia R. (2012) Models for forecasting airborne Cupressaceae pollen levels in central Spain. International Journal of Biometeorology, 56(2): 253-258

Schwendemann A.B., Wang G., Mertz M.L., McWilliams R.T., Thatcher S.L., Osborn J.M. (2007) Aerodynamics of saccate pollen and its implications for wind pollination. American Journal of Botany, 94(8): 1371-1381

Singh H. (1978) Embryology of Gymnosperms. Berl.-Stuttg., Gerb. Borntraeger, 304 p.

Southworth D. (1986) Pollen exine substructure III. Juniperus communis. Canadian Journal of Botany, 64(5): 983-987

Takaso T., Owens J.N. (2008) Significance of exine shedding in Cupressaceae-type pollen. Journal of Plant Research, 121(1): 83-85

Villar M., Knox R.B., Dumas C. (1984) Effective pollination period and nature of pollen-collecting apparatus in the Gymnosperm, Larix leptolepis. Annals of Botany, 53(2): 279-284

$$
-69-
$$


Wagner R.E., Mugnaini S., Sniezko R., Hardie D., Poulis B., Nepi M., Pacini E., von Aderkas P. (2007) Proteomic evaluation of gymnosperm pollination drop proteins indicates highly conserved and complex biological functions. Sexual Plant Reproduction, 20(4): 181-189

Williams C.G. (2008) Aerobiology of Pinus taeda pollen clouds. Canadian Journal of Forest Research, 38(8): 2177-2188 